\title{
Experimental study on the behaviour of nonductile infilled RC frames strengthened with external mesh reinforcement and plaster composite
}

\author{
S. Z. Korkmaz ${ }^{1}$, M. Kamanli ${ }^{2}$, H. H. Korkmaz ${ }^{2}$, M. S. Donduren ${ }^{2}$, and M. T. Cogurcu ${ }^{2}$ \\ ${ }^{1}$ Selcuk University, Engineering and Architecture Faculty, Architecture Department, 42250, Konya, Turkey \\ ${ }^{2}$ Selcuk University, Engineering and Architecture Faculty, Civil Engineering Department, 42250, Konya, Turkey
}

Received: 4 March 2010 - Revised: 19 July 2010 - Accepted: 21 October 2010 - Published: 18 November 2010

\begin{abstract}
The aim of this paper is to report on an experimental study about Turkish Earthquake Code on suggested strengthening method. The proposed method uses existing brick infill walls and the strengthening is done with the application of external mesh reinforcement and plaster. 5 nonductile $1 / 2$ scaled, one bay, two storey RC specimens were tested under a reversed cyclic loading. The first two specimens were reference specimens and the other ones were strengthened with the proposed method. The specimens contained several design and construction mistakes such as low concrete quality and improper steel detailing. Strength, stiffness and storey drifts of the test specimens were measured. The results of the test on these frames were compared with the reference specimens. The effects of the reinforced mesh plaster application for strengthening on behaviour, strength, stiffness, failure mode and ductility of the specimens were investigated. Unexpected failure modes were observed during the testing and the results were summarized in this paper.
\end{abstract}

\section{Introduction}

Many existing reinforced concrete (RC) frame structures, that were designed and constructed during the 1950s through to the 1990s, (according to the design codes of the 70s), in many regions of the Turkey, do not meet the current seismic design requirements set forth by the Turkish Earthquake Code (2007) and have an inadequate safety assessment (Rocha et al., 2004). A large number of those buildings exhibited fierce damage and some were on the verge of collapse (Oliveto and Decanini, 1998). Despite their rarity and moderate intensity, earthquakes not only in Turkey but

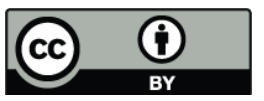

Correspondence to: M. Kamanli (mkamanli@selcuk.edu.tr) also in Europe and the USA have the potential to cause extensive damage and associated financial losses, due to the vulnerability of the local building stock (Belmouden and Lestuzzi, 2009). Reinforced concrete (RC) frame buildings with nonductile detailing represented a considerable hazard during recent earthquakes (Kaltakci et al., 2007). Structure that is not designed for prescribed earthquake forces suffered severe damage and was responsible for most of the loss of life during seismic events such as 1999 Kocaeli (Turkey) earthquake (Ghobarah and Elfath, 2001; Binici et al., 2007).

Those non-ductile RC frame structures may have inadequate lateral resistance and limited ductility. They possess an inherently low resistance to horizontal loads, resulting in large inelastic deformations (Zou and Teng, 2007) during recent earthquakes due to insufficient lateral load carrying capacity. For those structures constructed with insufficient strength and ductility, the required stiffness was not provided. The frames of these structures were designed to resist only gravity loads or gravity and moderate wind load. Older designs often do not have proper reinforcement details needed to ensure ductile behaviour (Geng et al., 1998; Ghobarah et al., 2000; Altin et al., 2007).

The load carrying system for most of the existing reinforced concrete residential buildings contains flexible columns, soft stories and strong-beam weak-column connections (Altin et al., 2008). Reinforced concrete buildings designed without seismic considerations have significant deficiencies, such as, poor confinement of the column lap splice area (Ghobarah and Elfath, 2001) (due to the insufficient amount of ties with $90^{\circ}$ hooks), discontinuity of positive moment reinforcement in beams and slabs resulting in bond slip of beam bottom reinforcement at the joint (Hueste and Bai, 2007), lacking transverse shear reinforcing steel, having plain bars and low strength concrete (10$15 \mathrm{MPa})$. In 1999, Marmara earthquake caused substantial casualties and severe damage to structures (Firat et al., 2009).

Published by Copernicus Publications on behalf of the European Geosciences Union. 
Table 1. Summary of the test specimens.

\begin{tabular}{|c|c|c|c|c|}
\hline $\begin{array}{l}\text { Specimen } \\
\text { name }\end{array}$ & Definition & $\begin{array}{l}\text { Strengthening } \\
\text { plaster } \\
\text { thickness }\end{array}$ & Observed failure type & Lap splice condition in columns \\
\hline RFB1 & Reference specimen with no infill & - & Flexural & - \\
\hline RISPS2 & Reference specimen with infill & - & Corner crushing of the infill wall panels & - \\
\hline SPS1 & Strengthened & $15 \mathrm{~mm}$ & $\begin{array}{l}\text { Premature failure - } \\
\text { shear failure of dowels and plaster }\end{array}$ & Insufficient lap splice length \\
\hline SPS2 & Strengthened & $30 \mathrm{~mm}$ & Lap splice failure & Insufficient lap splice length \\
\hline SPS3 & Strengthened & $30 \mathrm{~mm}$ & Frame joint failure & Lap splice was improved \\
\hline
\end{tabular}

After the Marmara earthquake, it was observed that, failure of reinforced concrete columns usually occurred in potential plastic hinge regions at the bottom. The reason was, lap splices in the column longitudinal reinforcement was located at member ends, and the lengths of splices were often shorter than those required by building codes. The consisting building stock must be prepared for future earthquakes (Onal, 2009) and easily applicable and occupant-friendly new strengthening methods should be developed.

\section{Materials and methods}

In the experimental study, a total of five $1 / 2$ scale, onebay, two-storey nonductile RC frame specimens were manufactured and tested as part of the experimental program (Kilic, 2010). The model ratio of the specimens definitely affect the validity of the test results. On the other hand, production of specimens in real dimensions is costly considering the limited budget of the test programme and creates lifting and destruction problems. Another problem is the load capacity of the available hydraulic cylinders and loading setup. On the other hand, several studies in the literature (Binici et al., 2007; Anil et al., 2007; Erdem et al., 2006; Altin et al., 2008) used 1/3 model ratio which was smaller than $1 / 2$ model ratio of the current study.

Two specimens, which were reference specimens and the remaining three of which had deficient reinforcement detailing were prepared. The first specimen tested was a bare frame with no infill wall. The second reference specimen was infilled with ordinary perforated clay bricks. The other three specimens were strengthened with the details given in the new Turkish Earthquake Code (2007). In all test specimens, the geometric dimensions and reinforcement patterns of the frames were identical. Structural characteristics of the specimens were summarized in Table 1.

During the design phase of the frames, some deficiencies commonly observed in structures were purposely included to reflect the gravity load designed residential buildings in Turkey. Insufficient confinement of concrete at the column and beams with ties having $90^{\circ}$ hooks at their free ends, weak-column, strong-beam connections that are encountered frequently in practice and frames with inadequate lateral stiffness was provided. Also no confinement was provided at beam-column joints.

The total height of the specimens was $3 \mathrm{~m}$. The column dimensions were $160 \times 240 \mathrm{~mm}$ and the beam dimensions were $240 \times 240 \mathrm{~mm}$. In the columns the longitudinal reinforcement consists of four $12 \mathrm{~mm}$ diameter plain bars $(\rho=0.0082)$. In the beams, three tension and three compression reinforcements were placed. In total, six $12 \mathrm{~mm}$ diameter plain bars were used as longitudinal reinforcement (effective depth of the beam $d=24-2^{*} 1=22 \mathrm{~cm}, b_{\mathrm{w}}=$ $\left.22 \mathrm{~cm}, \quad \rho^{\prime}=0.0064\right)$. Plain bars with a diameter of $8 \mathrm{~mm}$ spaced at $150 \mathrm{~mm}$ were used as closed stirrups in both the beams and columns. Since specimens were $1 / 2$ scaled models of the real structure, $150 \mathrm{~mm}$ stirrup spacing corresponds to the $300 \mathrm{~mm}$ interval in real RC members. The longitudinal reinforcements in columns were lap spliced, both at foundation level and first (middle) storey level. The lap length was chosen as $200 \mathrm{~mm}$. Dimensions and reinforcement details of the test frames are shown in Fig. 1. Also in Fig. 1, reinforcement details of the joints and stirrup spacings were illustrated.

The frames of the specimens were cast from very low strength concrete to represent the strength of concrete in existing buildings. Based on concrete trial mixes from various recipes for attaining the 28-day target strength of $10 \mathrm{MPa}$, a design mix was determined. Although the minimum concrete strength stated in the Turkish Earthquake Code is $20 \mathrm{MPa}$ for the 1 st earthquake zone, existing structures commonly have a low quality of concrete. This has been observed by several researchers (Kaltakci et al., 2008; Arslan et al., 2007). Cylinder tests were performed and the concrete strength was approximately $10 \mathrm{MPa}$ at the day of testing. The maximum size of aggregate for $1 / 2$ scale model specimens was $16 \mathrm{~mm}$. The average compressive strength of the mortar and the plaster used in the construction of the masonry walls of specimens was found to be $2.6 \mathrm{MPa}$. Plain bars were used as the reinforcing steel since such steel has been used in most of the existing residential buildings in Turkey. 


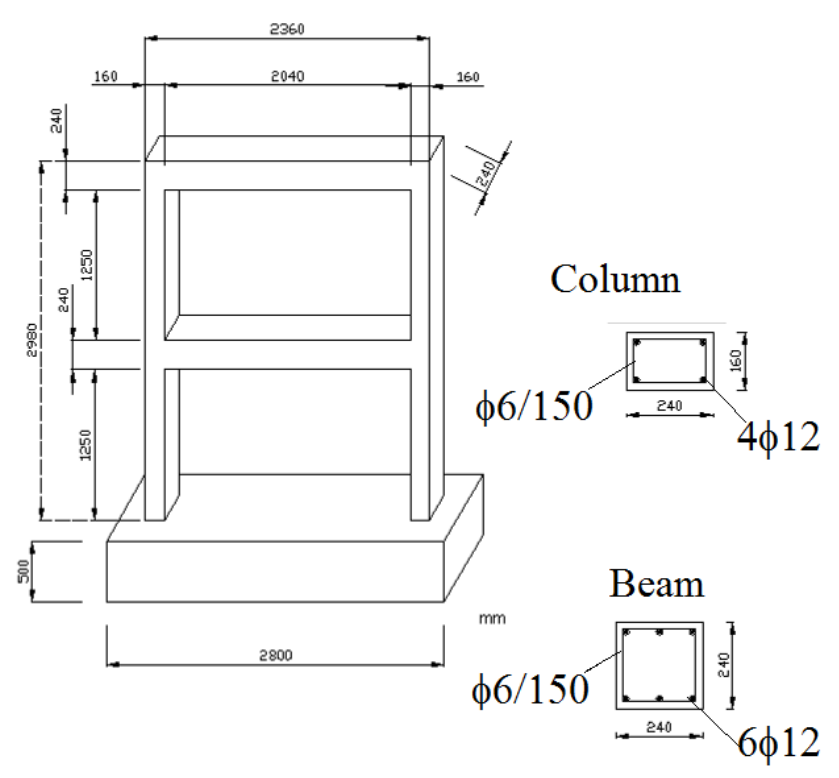

(a) general details

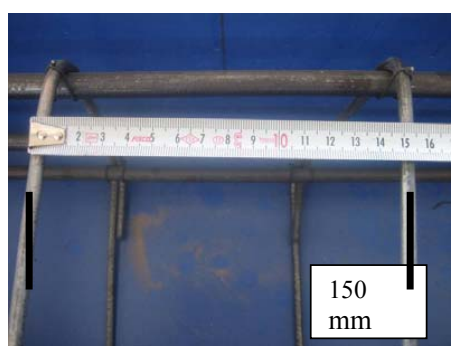

(b) stirrup spacing

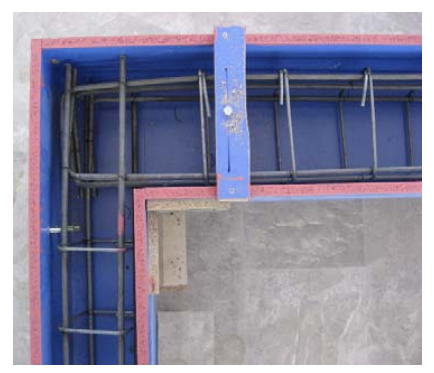

(d) top storey beam-column joint detail

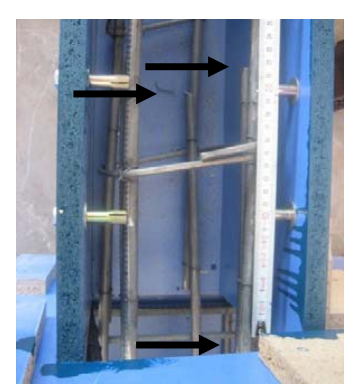

(c) column bottom lap splice detail

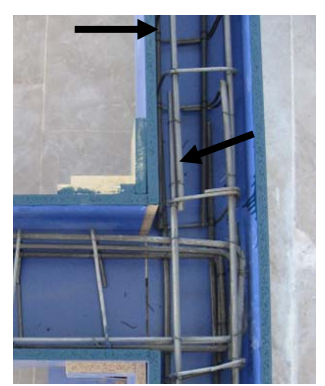

(e) middle storey beam-column joint detail

Fig. 1. Dimensions and details of the test specimens.

The strengthening technique was applied according to the specification described in Turkish Earthquake Code (2007). After the specimens were lifted to the vertical position, brick infill walls were constructed by an ordinary worker. The $1 / 2$ scaled clay bricks were used and ordinary mortar was used. The bricks were laid in such a way that their holes were parallel to the horizontal plane. The thickness of the wall was $100 \mathrm{~mm}$ ( $1 / 2$ scale) which is $200 \mathrm{~mm}$ in an ordinary exterior wall of a residential building. Infill walls were not constructed on the symmetry axis of the frame for simulating

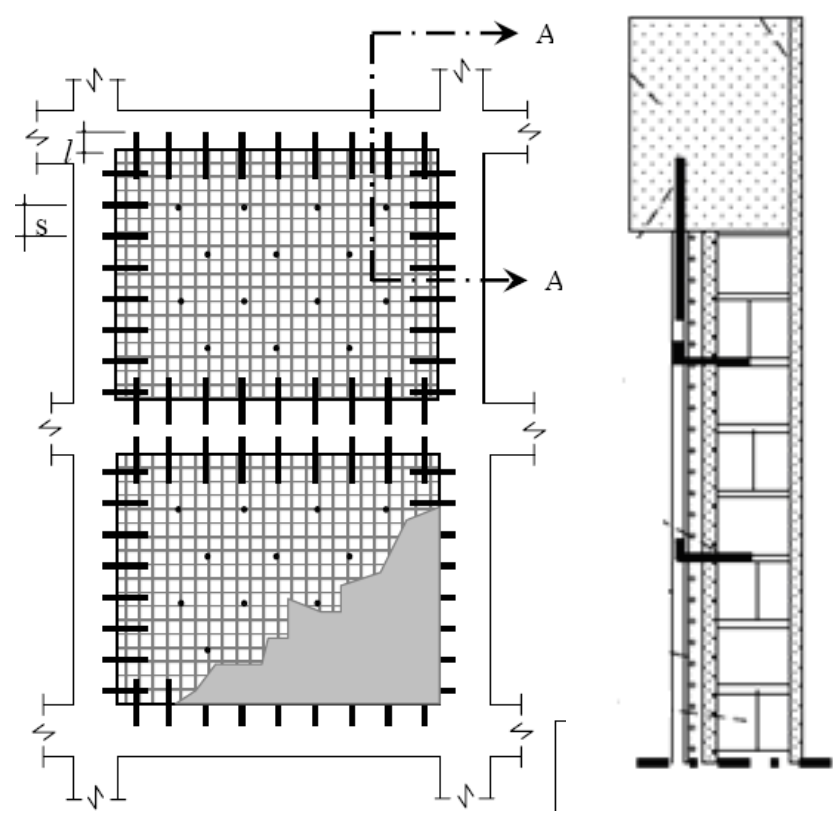

Fig. 2. Plastered walls with welded external mesh and plaster composite (TEC-2007).

exterior walls of the building. One face of the wall was on the same line of the columns while the other face was $140 \mathrm{~mm}$ inside the other exterior face of the columns.

The external mesh reinforcement consisted of $16 \times 16 \mathrm{~mm}$ square meshes with $1.1 \mathrm{~mm}$ diameter steel. The shear connections between the frame and infill walls were established with dowel reinforcements. These dowels were attached to the inner faces of the beams and columns with $160 \mathrm{~mm}$ intervals in horizontal and vertical directions. The $10 \mathrm{~mm}$ diameter bars were used as dowel reinforcement and they were anchored to the RC members with epoxy. Holes, which were drilled on the inner faces of the frame members, were cleaned. The mesh reinforcement was placed on the infill wall and the dowels were inserted into epoxy injected holes. The infill wall reinforcement was also $1 / 2$ scaled. Since both reinforcement and wall was scaled down, the ratio was not changed and chosen as $\rho_{\mathrm{v}}=\rho_{\mathrm{h}}=0.009$ in both vertical and horizontal directions.

The plaster mixes were prepared according to the proportion given in TEC-2007. Both sides of the wall were plastered with the prepared plaster material. The thickness of the plaster was $15 \mathrm{~mm}$ and the total thickness of the masonry wall with plaster was $130 \mathrm{~mm}$. The thickness of the plaster was $1 / 2$ scaled and in real application it is approximately $30 \mathrm{~mm}$. The representative illustration of the strengthening application is given in Fig. 2. In a real application an older plaster layer exists and strengthening was applied over the older plaster layer. In experimental studies, the strengthening was directly applied over the infills, the contribution of the old plaster was ignored. 
Table 2. Mechanical properties of the materials.

\begin{tabular}{lrrl}
\hline & $\begin{array}{r}\text { Modulus } \\
\text { of } \\
\text { Elasticity }\end{array}$ & $\begin{array}{r}\text { Copmressive } \\
\text { Strength }\end{array}$ & $\begin{array}{l}\text { Yield } \\
\text { Strength }\end{array}$ \\
\hline $\begin{array}{l}\text { Concrete } \\
\text { Longtidional } \\
\text { reinforcement }\end{array}$ & $200000 \mathrm{Mpa}$ & $10 \mathrm{Mpa}$ & \\
$\begin{array}{l}\text { Transverse steel } \\
\text { Mesh }\end{array}$ & $200000 \mathrm{Mpa}$ & & $480 \mathrm{Mpa}$ \\
reinforcement & $250000 \mathrm{Mpa}$ & & $480 \mathrm{Mpa}$ \\
$\begin{array}{l}\text { Steel dowels } \\
\begin{array}{l}\text { Ordinary plaster } \\
\text { Strengthening }\end{array}\end{array}$ & $21000000 \mathrm{Mpa}$ & & $520 \mathrm{Mpa}$ \\
plaster & $20000 \mathrm{Mpa}$ & $2.6 \mathrm{Mpa}$ & \\
Masonry bricks & Not tested & $5 \mathrm{Mpa}$ & \\
\hline
\end{tabular}

The modulus of elasticity of the materials and other mechanical properties were summarized in Table 2 .

\section{The testing system}

The laboratory of the University contains a strong floor with $600 \mathrm{~mm}$ thickness and having uniformly distributed holes with $70 \mathrm{~mm}$ in diameter. There is also a strong reaction wall, with a $12 \mathrm{~m}$ height. Specimens were cast in a horizontal position and then lifted to a vertical position. Production of the specimens in the vertical position created form and scaffolding problems, making the leveling of the form of the specimens very difficult. In another experimental programme, authors produced two specimens, one of which was casted in a vertical position and another in a horizontal position. No clear differences under lateral loading was observed. So authors preferred the horizontal casting for ease of production. The specimens were built on stiff reinforced concrete foundations and bolted to the rigid floor through holes with high strength steel bolts. The lateral loading equipment consisted of a hydraulic jack with a $1000 \mathrm{kN}$ capacity and three loadcell with a $500 \mathrm{kN}$ capacity. Tests were conducted under reversed cyclic lateral loading simulating seismic action. Lateral load was applied to specimens at the storey levels. Cycles were named as forward and backward cycles and forward cycles were assumed to be positive. Axial load was also applied to the top of the columns with two hydraulic cylinders and was measured with two loadcells. A special apparatus was manufactured to apply axial load. The representation of the test setup, loading system and instrumentation is shown in Fig. 3.

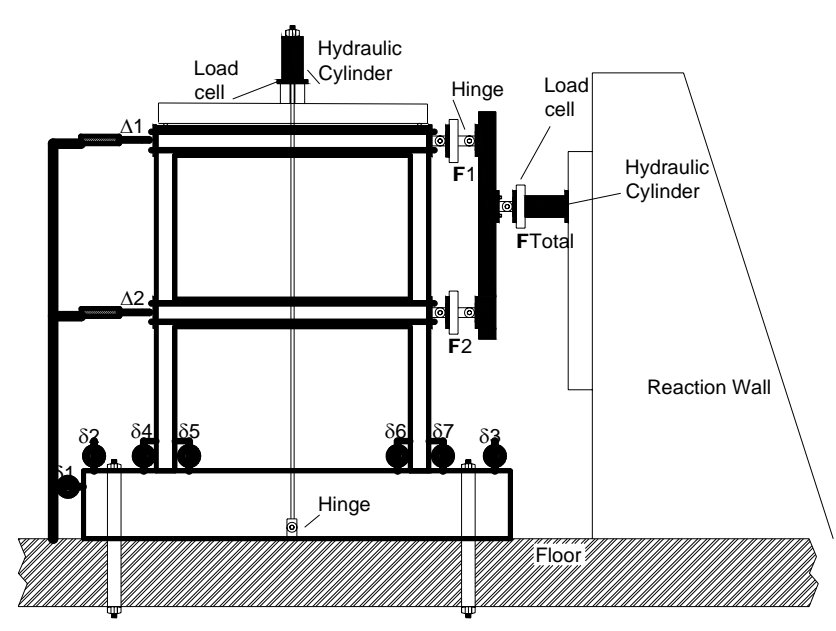

Fig. 3. Test setup, loading system and instrumentation.

The instrumentation setup consisted of LVDT's, and data acquisition system. The specimens were instrumented with LVDTs (linear variable differential transformers) to measure top and middle story displacements. During the tests, story displacements and the lateral loads were saved to the computer and monitored simultaneously. Cyclic lateral displacement excursions were imposed to simulate the seismic demand. The lateral load was applied with a rigid steel beam such that $1 / 3$ and $2 / 3$ of the total load was applied on the middle and top storey, respectively. Loading cycles consisted of preyield and post yield cycles. In the elastic range several cycles were applied with a load controlled history. Beyond the elastic limit, displacement controlled cycles were applied. The maximum displacement capacity of the test setup was $100 \mathrm{~mm}$ which corresponds to the $3 \%$ drift ratio. During the loading cycles, when target load or displacement was reached, the loading was stopped and new initiated cracks and crack propagation were marked on the specimens and failure mechanisms were observed.

\section{Results}

In this section, experimental results were summarized with hysteresis curves of the specimens. The vertical axis of the curves represents the top lateral load in $\mathrm{kN}$ and the bottom horizontal axis is the top displacement in $\mathrm{mm}$. Top horizontal axis is the lateral drift percentage of the frame. Also in curves, drift levels corresponding to $0.4 \%$ and $1.2 \%$ were highlighted. The failure points of the specimens were marked with a black circle.

A reference specimen with no infill wall was prepared and tested to understand the bare frame capacity and named as RFB1 (Fig. 4). Load-top displacement hysteresis curve of the specimen is represented in Fig. 5. The displacement levels of the initial elastic cycles did not generate any nonlinear deformation in the structure and the loops followed a straight 


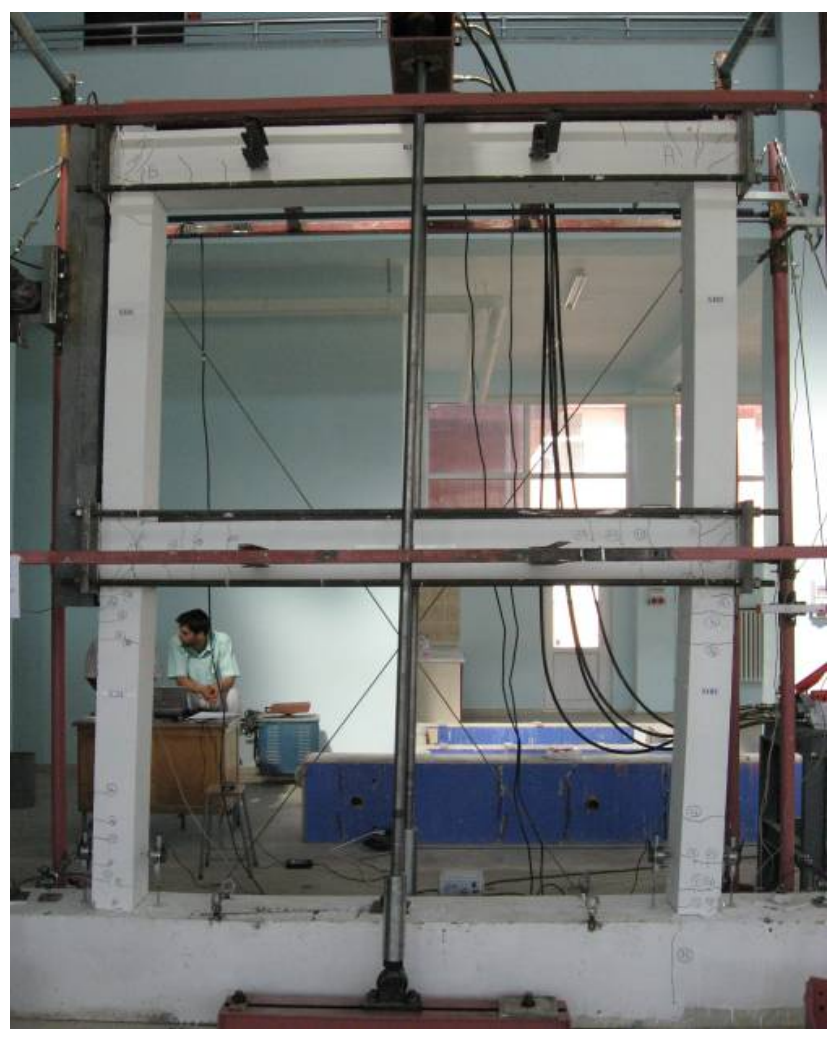

Fig. 4. Reference bare frame RFB1.

line. The maximum load carrying capacity of the specimen was determined as $34.5 \mathrm{kN}$. Plastic hinges were formed in the beam-column joints. No obvious failure point can be determined in specimen RFB1. Several flexural cracks were observed both on the beams and the columns. The onset of stiffness degradation was identified by simultaneous formation of tension cracks at the bottom of the columns.

As observed from Fig. 4 , the $\Delta 1$ and $\Delta 2$ readings were not displayed linear increase. Actually, before the occurrence of the plastic hinges, the variation is linear, but after the elastic limit, several plastic hinges were formed in the ends of beams or columns and linearity was disturbed.

Second reference specimen RISPS2 was manufactured with the same reinforcement details of RFB1. The concrete compressive strength was the same with the RFB1. The frame was infilled with masonry wall panel. No strengthening was applied on the wall. Ordinary plaster was applied on both surfaces of the masonry wall.

During the testing, it was observed that, at low levels of lateral forces, the frame and infill wall behave monolithically. However, as the lateral force level increases, the frame deforms in a flexural mode while the infill corners damaged. In the early stages of the loading, the frame with infill wall displayed higher in-plane stiffness and strength. The mentioned increase can be seen from the hysteresis curves of the specimen RISPS2 (Fig. 6).

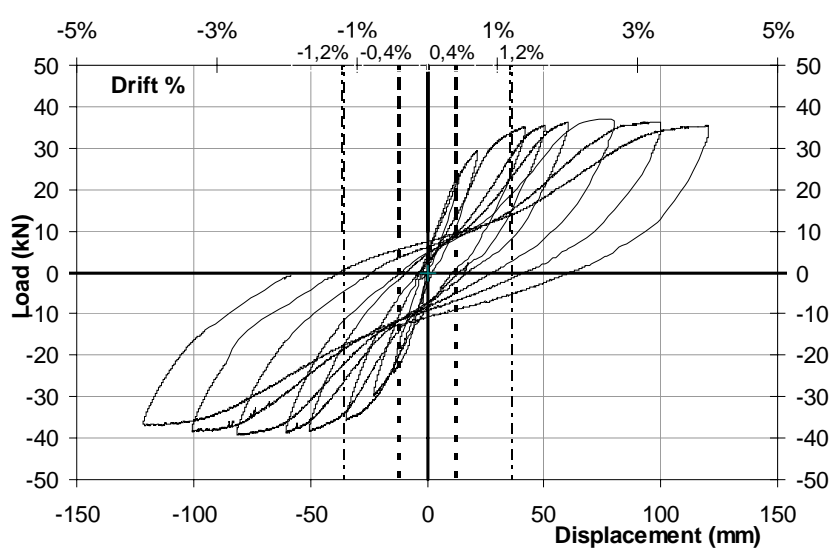

Fig. 5. Load-top displacement hysteresis curve of reference bare frame RFB1.

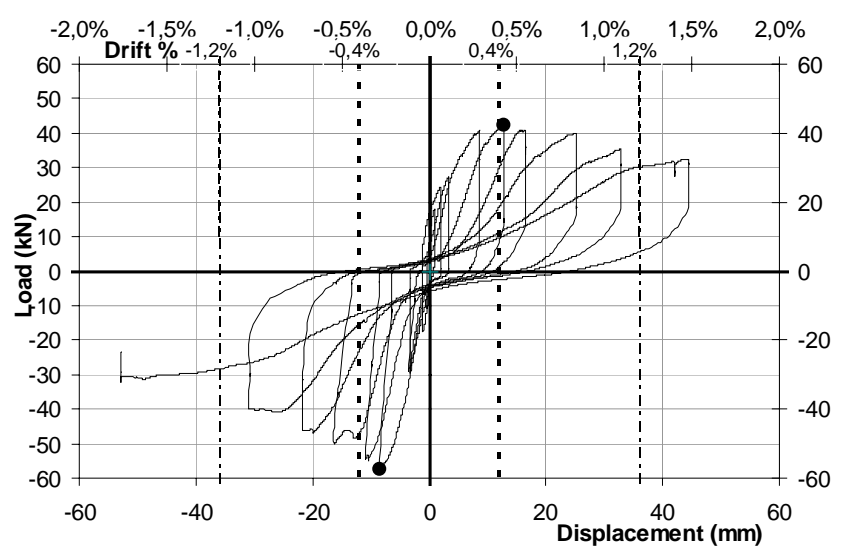

Fig. 6. Load-top displacement hysteresis curve of reference infilled frame RISPS 2 .

Shing and Mehrabi (2002) identified five main failure mechanisms of infilled frames. Those failure modes are; flexural mode, horizontal sliding crack at the mid-height of an infill, diagonal cracking, sliding of multiple bedjoints (a distinct diagonal strut mechanism with two distinct parallel cracks) and corner crushing. In summary, the failure mechanism and load resistance of an infilled frame depend very much on the strength and stiffness of an infill with respect to those of the bounding frame.

In the test of the specimen RISPS2, fifth mode of the failure was observed. The corners of the wall panels damaged and crushed. Separation of the infill from the frame was obvious at the higher displacement levels. Both upper and bottom wall panels damaged. The failure mode and specimen at the end of the test is given in Fig. 7. RISPS2 specimen survived 22\% higher lateral load than RFB1 specimen.

Third specimen was named as SPS1. The frame properties and infill configuration was the same with RISPS2 specimen. The strengthening scheme was applied as explained before (Fig. 8). 

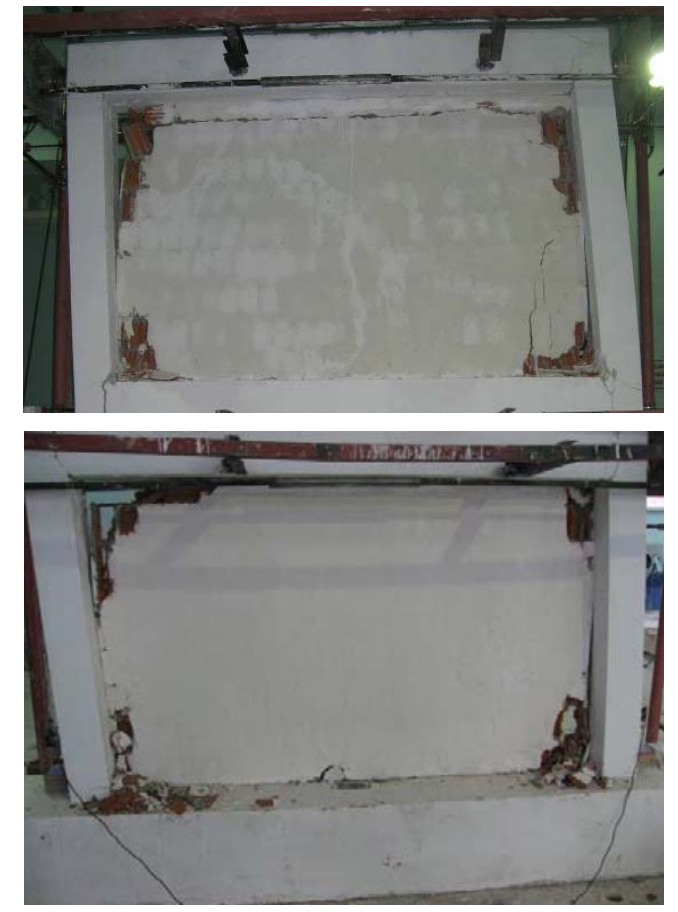

Fig. 7. Reference infilled frame RISPS2.

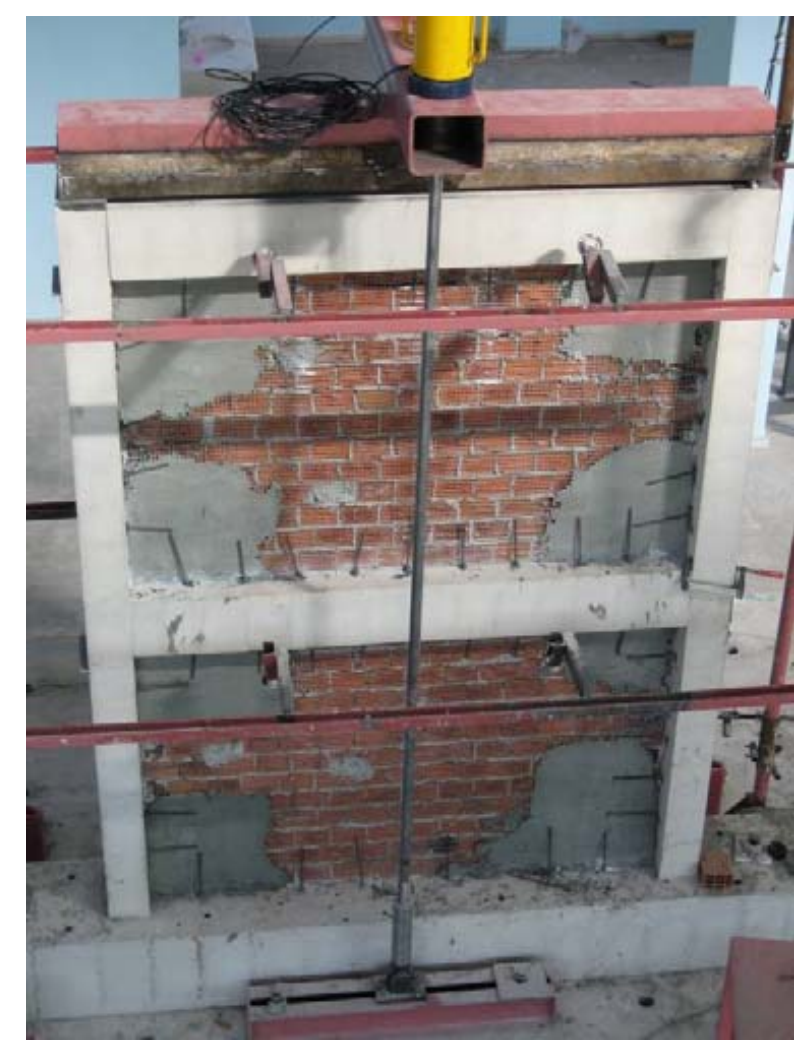

Fig. 8. Strengthening of specimen SPS1.

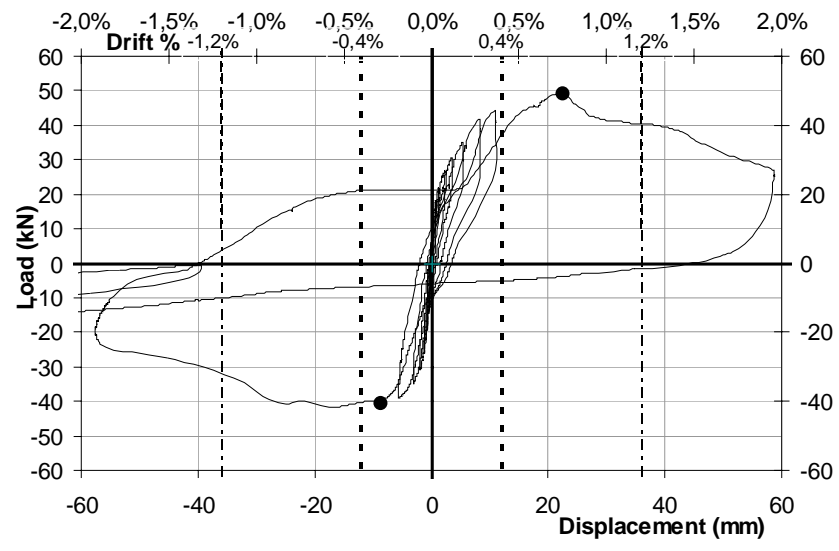

Fig. 9. Load-top displacement hysteresis curve of SPS1.

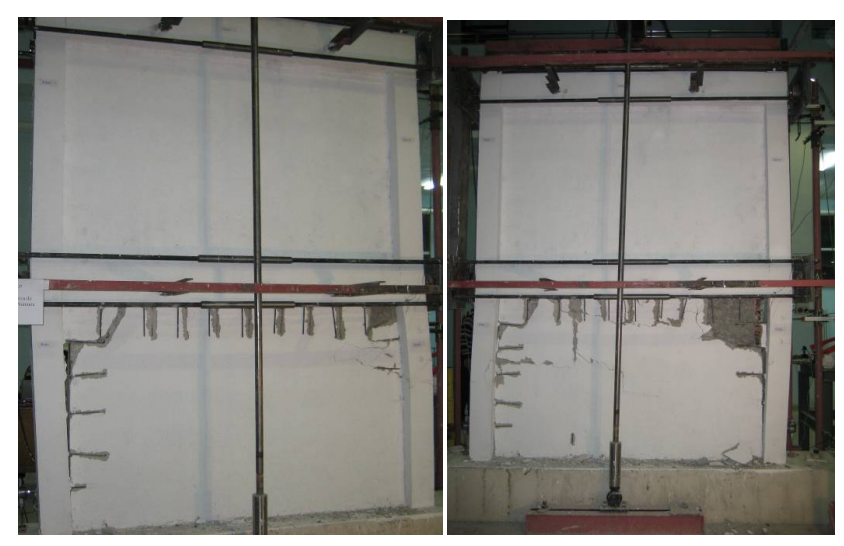

Fig. 10. Failure mode of specimen SPS1.

Although specimen SPS1 survived 16\% higher maximum lateral loading, its performance was evaluated as poor. The dowels or shear keys below the middle beam disintegrated from the plaster and lateral displacement of the frame suddenly increased. At this time there was also a sudden drop in the load carried by the system. The failure point of the dowels-wall-plaster composite can be clearly seen from the last cycle of the load-displacement hysteresis curve (Fig. 9).

After the failure of the dowels, the testing could not continue. The failure mode of the specimen is given in Fig. 10. During testing, the wall panels of specimen SPS1 showed a higher stiffness contribution to the frame than the RFB1 and RISPS2. Also the ultimate lateral load carrying capacity of the SPS1 was increased as compared to SPS1 and RISPS2. Several flexural cracks were observed on the beams and columns. But below the first storey beam, premature and sudden failure of the wall-plasterdowel interface was observed. The plaster cover over the dowels disintegrated and no more shear transfer between the beam and the wall were possible. This failure mode was 
very sudden and brittle in nature. The full capacity of the mesh-plaster-wall composite could not be used due to this premature failure. After the failure, the specimen showed similar load-displacement characteristics with the RISPS2 specimen. This failure was attributed to inadequate plaster thickness and at the end of the test, it was decided to increase the thickness of the plaster. This specimen lost $55 \%$ of its lateral load carrying capacity immediately after failure of the dowel anchorage with the mesh plaster composite.

After obtaining a dowel-plaster anchorage failure in specimen SPS1, the thickness of the plaster was increased to $30 \mathrm{~mm}$ in specimen SPS2 (Fig. 11). Other properties were the same as SPS1. During the test of SPS2, no damage was observed on the wall panels, but instead some minor cracks formed. Serious cracks were observed on both column bases. These cracks were also extended through the bottom of the lower wall panel (Fig. 12).

The lateral load-top storey displacement hysteresis curves are presented in Fig. 13. The maximum lateral load obtained during the testing was $63.2 \mathrm{kN}$, which was $82 \%$ higher than bare frame and 50\% higher than the reference infilled specimen. The wall panels contributed to the load carried by the system and also increased the stiffness of the frame, but failure of the panel could not be obtained. The reason for the failure attributed to the slippage of the reinforcing bars at the bottom of the columns. The low concrete strength, plain undeformed bars and insufficient lap splice length at the joint created such a failure mode.

Specimen SPS3 was prepared according to the results obtained in the SPS2 testing. The bottom joints of the columns were improved by increasing the lap length of the longitudinal reinforcements. The $200 \mathrm{~mm}$ lap length was increased to $420 \mathrm{~mm}(20 \mathrm{f} \times 1.5)$ lap length which was applied in the Turkish Earthquake Code. Other properties were as SPS2. The maximum lateral load carried by the system was obtained as $69 \mathrm{kN}$. No lap splice failure was observed at the bottom of the columns. Also dowel-plaster failure did not form. The specimen survived a $10 \%$ higher lateral load than SPS2. On the other hand, as the load levels increased, several cracks were concentrated on the middle beam-column joint and those cracks determine the failure mode. Middle joints were seriously damaged and the lateral load carried by the system dropped drastically. Left and right joint failure photos are given in Fig. 14 and 15, respectively.

The column stirrups did not exist in the beam column joints. Also lap splice length of the column's longitudinal reinforcement was insufficient at those points. In addition to these detailing mistakes, another effective parameter to the failure was poor concrete quality. The lateral load at the joints was transferred to the foundation, through diagonal struts along the wall panel. As a result, inclined inner forces were acting on the joints. Since the joints did not have enough confinement and strength, they failed. The failure point of the joints can also be seen from load hysteresis curves (Fig. 16).

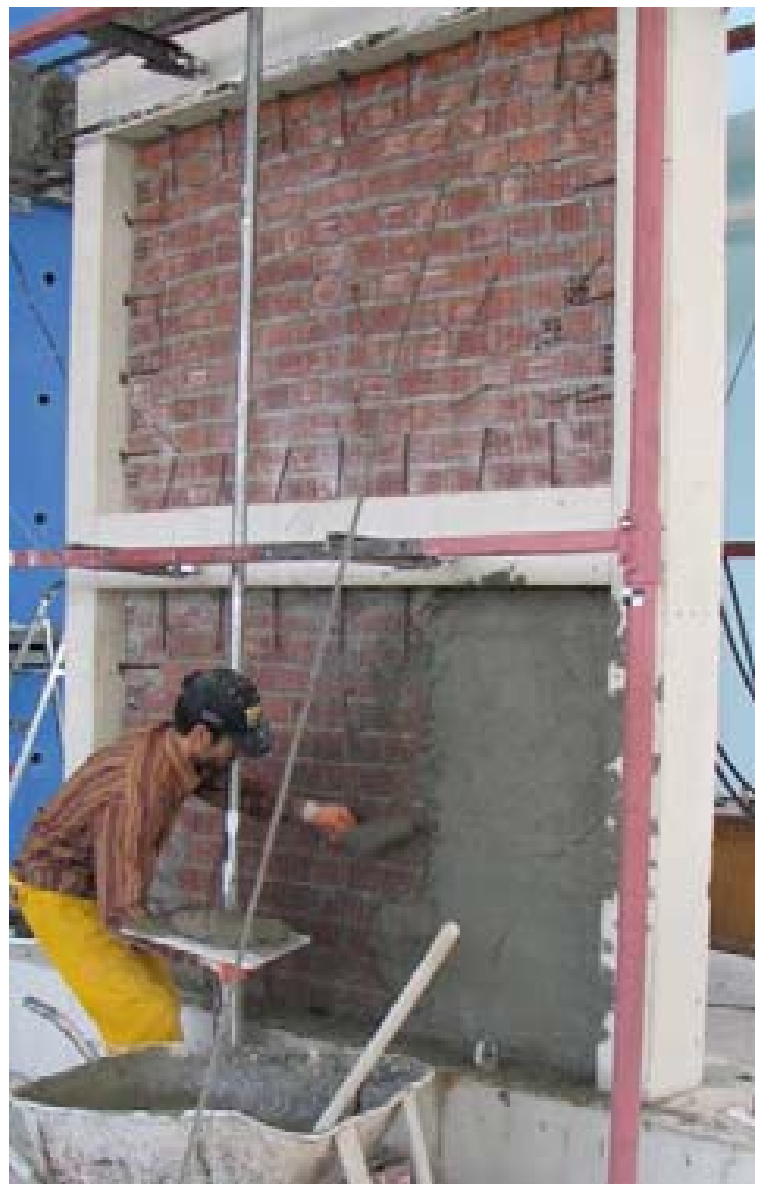

Fig. 11. Preparation of specimen SPS2.

\section{Comparison of results}

The lateral load-top displacement characteristics for all the specimens are presented and compared in this section. The comparison of the behaviour of the test specimens is made in terms of lateral strength, stiffness, maximum storey drifts and energy dissipation characteristics. The envelopes let us compare the relative performance of the specimens. To enable the comparison among the test specimens studied here, the load-displacement envelopes are plotted by connecting the maximum peak points of consecutive hysteresis curves. The response envelope curves of the strengthened specimens are given in Fig. 17 together with that of the reference bare frame and reference infilled specimen. These plots have a better representation of the rate of stiffness degradation. As can be seen from this figure, strength and stiffness of both strengthened frames were significantly higher than those of the reference specimens

Also in Fig. 18, the comparison ratio of the ultimate lateral loads to the reference empty specimen RFB1 is given in a clustered column type chart. This figure lets us compare the relative performance of the specimens. 

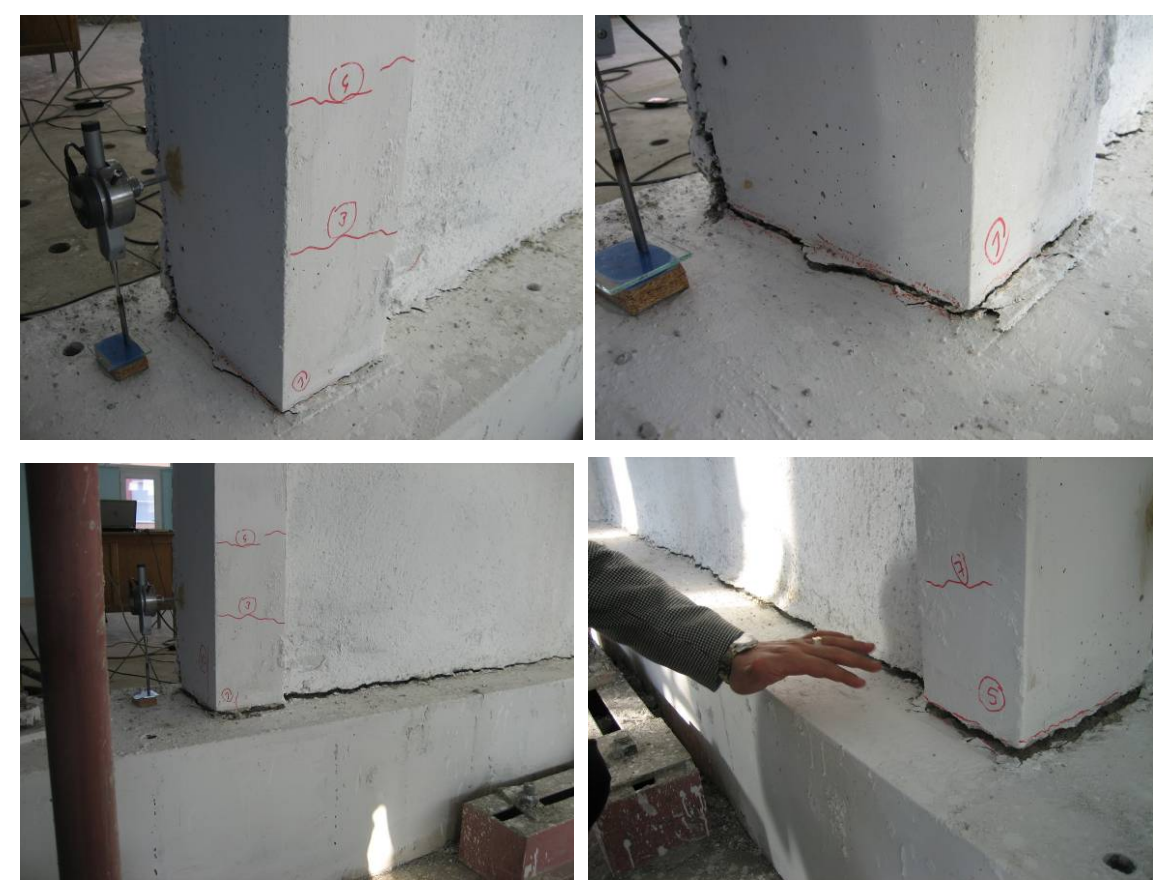

Fig. 12. Slip failures at the bottom of the columns.

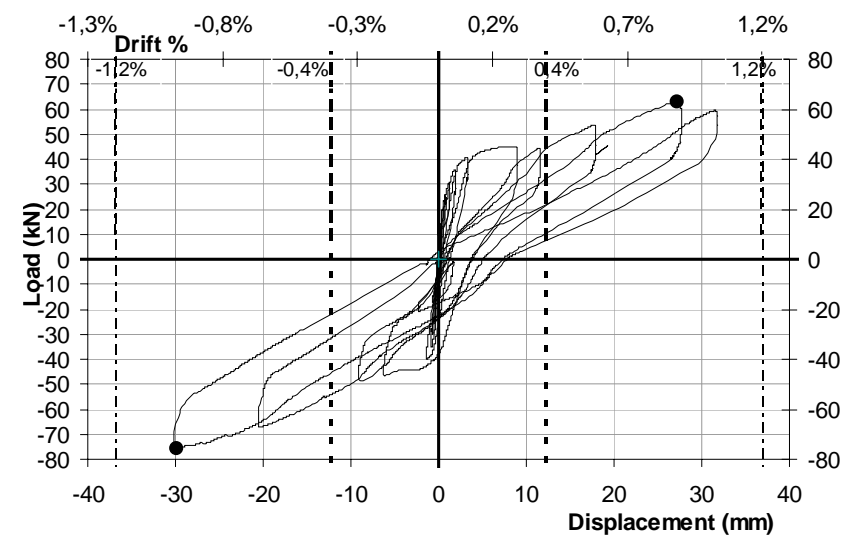

Fig. 13. Hysteresis curves of specimen SPS2.

The maximum ultimate load was obtained in Specimen SPS3 and a relatively low ultimate load capacity was observed in Specimen SPS1. From this figure, the contribution of the infill can be seen (RISPS2) as compared to the bare frame capacity. By examining Figs. 17 and 18, it can be concluded that, both the strength and the stiffness were significantly improved by introducing external mesh reinforced infill.

Another phenomenon that must be considered for comparison purposes is the maximum drift of the frame. The deformation control is important to ensure the serviceability requirements (Dundar and Kara, 2007). In the design process of reinforced concrete buildings, the serviceability limit state for lateral drift is an important design criterion that must be satisfied to prevent large second-order P-delta effects. All Seismic Codes provide limits to prevent extensive structural and non-structural damage and to minimize the second order effects (Erdem, 2006). Turkish seismic code specifies the interstorey drift limit as 0.02 for the RC framed systems, yet this value in Eurocode 8 regulations, for brittle nonstructural infills in contact with the RC frame, is taken equal to $0.5 \%$ (Altin et al., 2007). Calvi (2000) states that the $0.4 \%$ drift corresponds to the condition called "design earthquake" while $1.2 \%$ drift represents the "extreme earthquake" one. The maximum drift $(\Delta \max )$ was approximated as the drift ratio corresponding to the strength deteriorated by $20 \%$ of the ultimate load (0.8 times ultimate load-Vmax) (Han and Jee, 2005). The calculated maximum load Vmax, corresponding top displacements were presented together with the yield point at $0.75 \times V \max$ and the ultimate drift limit at $0.8 \times$ Vmax were tabulated in Table 3 .

For specimen RISPS2 and SPS1, maximum drift ratios were 1.99 and 1.31, respectively. External mesh reinforcement application caused a decrease in the drift value, but it was also above the code requirements. Also for specimens SPS2, this drift ratio corresponding to the $20 \%$ of the ultimate load is 1.69 . The slip at the bottom of the columns increased the drift ratio of the specimen. The minimum drift was obtained in the SPS3 specimen, which was 1.19. The measured storey drift ratios for all the strengthened specimens at ultimate load were greater than the limit drift ratio that was suggested by the regulations. 

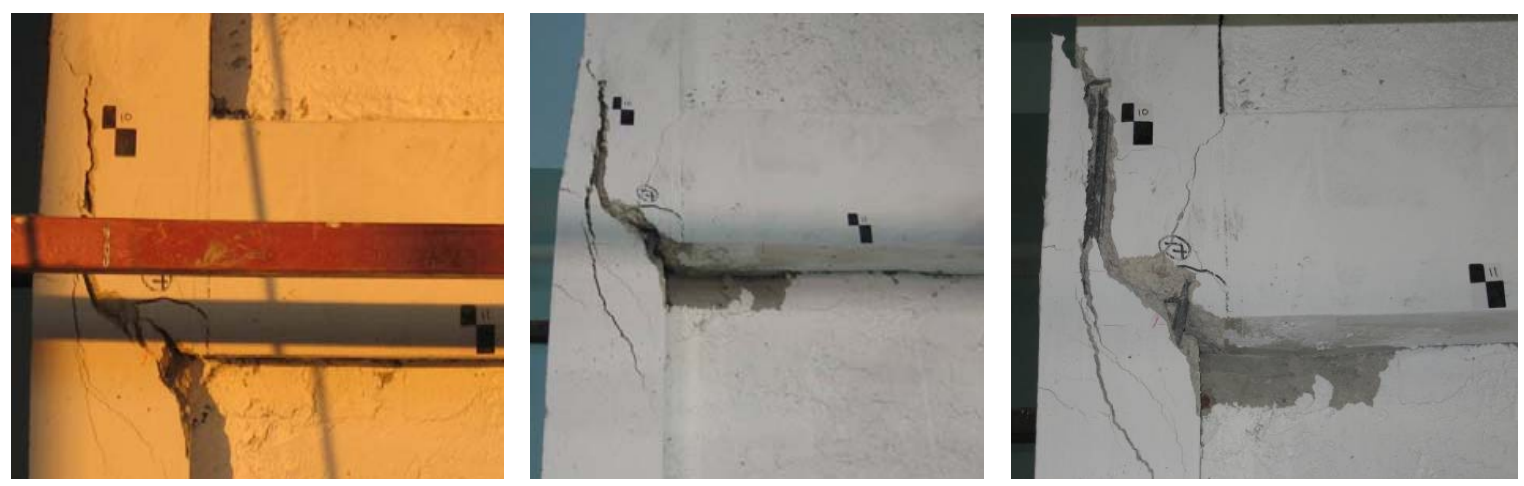

Fig. 14. Failure of the left beam-column joint.
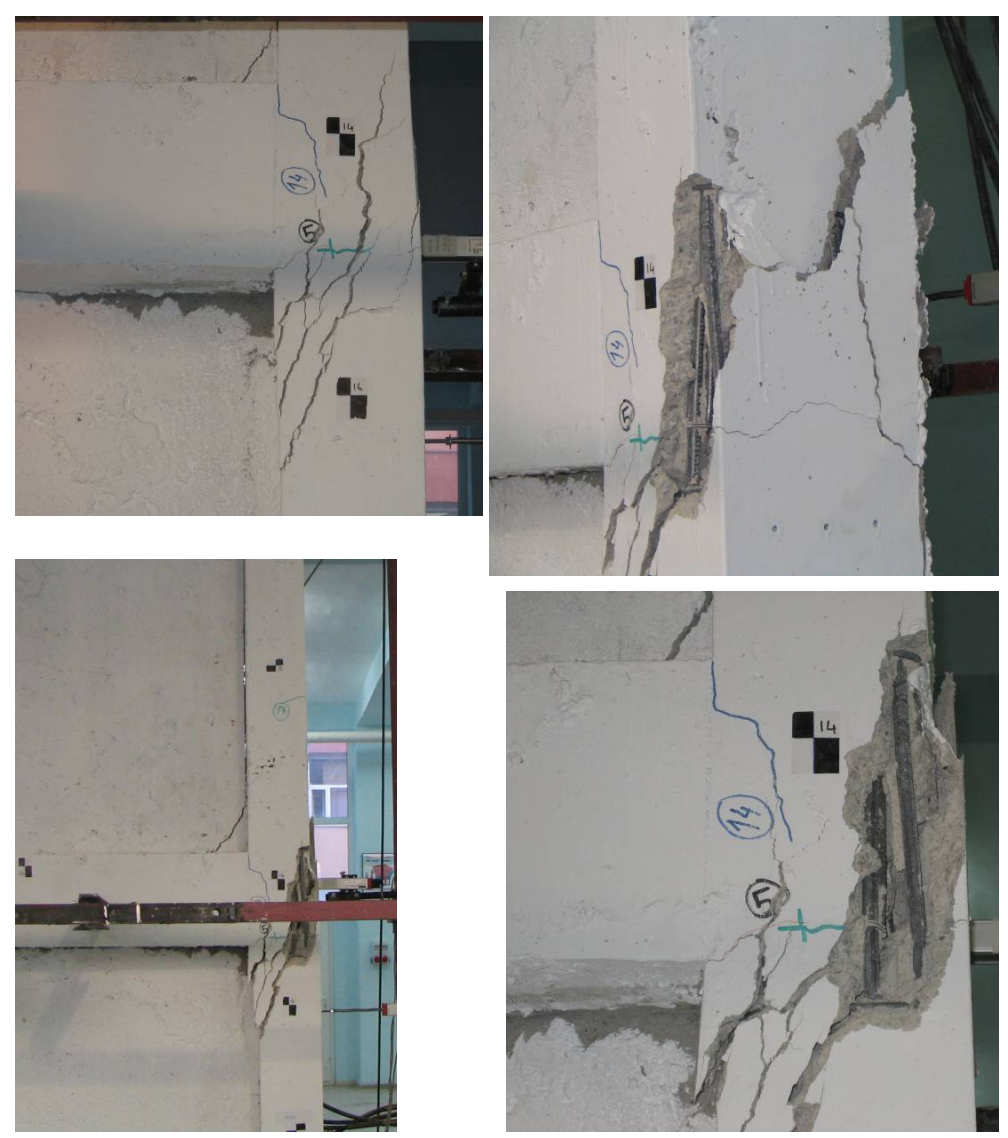

Fig. 15. Right beam-column joint failure.

Table 3. Ultimate load and drift values with yield load and displacement values.

\begin{tabular}{llllllll}
\hline & $\begin{array}{l}\text { Displacement } \\
(\mathrm{mm})\end{array}$ & $\begin{array}{l}\text { Max. Load Vmax } \\
(\mathrm{kN})\end{array}$ & $\begin{array}{l}\text { Displacement } \\
(\mathrm{mm})\end{array}$ & $\begin{array}{l}0.75 \times \text { Vmax } \\
(\mathrm{kN})\end{array}$ & $\begin{array}{l}\text { Displacement } \\
(\mathrm{mm})\end{array}$ & $\begin{array}{l}0.8 \times \text { Vmax } \\
(\mathrm{kN})\end{array}$ & $\begin{array}{l}\text { Story drift } \\
(\%)\end{array}$ \\
\hline RFB1 & 40.00 & 34.51 & 16.70 & 25.88 & - & 27.61 & - \\
RISPS2 & 12.71 & 42.41 & 5.13 & 31.81 & 59.76 & 33.93 & $1.99 \%$ \\
SPS1 & 22.39 & 49.29 & 7.48 & 36.97 & 39.43 & 39.43 & $1.31 \%$ \\
SPS2 & 27.39 & 63.30 & 13.84 & 47.47 & 50.63 & 50.64 & $1.69 \%$ \\
SPS3 & 9.97 & 69.01 & 16.71 & 51.75 & 35.56 & 55.20 & $1.19 \%$ \\
\hline
\end{tabular}




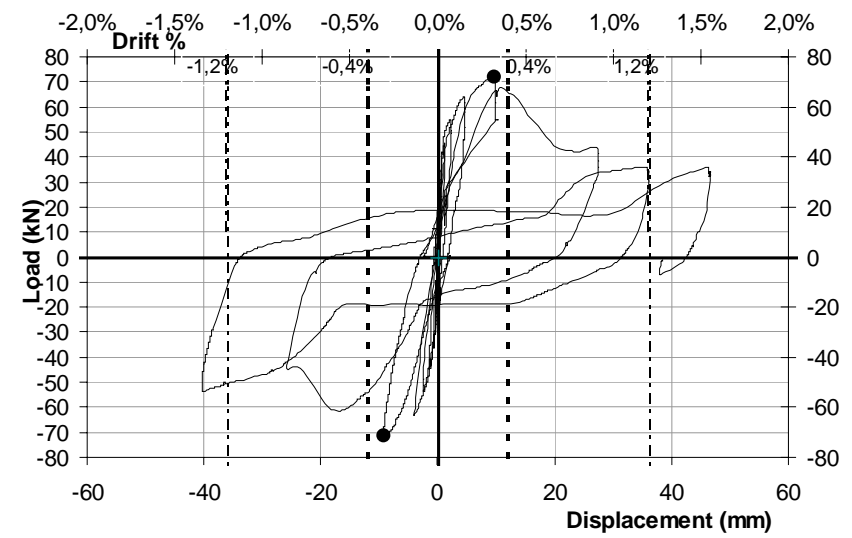

Fig. 16. Hysteresis curves of specimen SPS3.

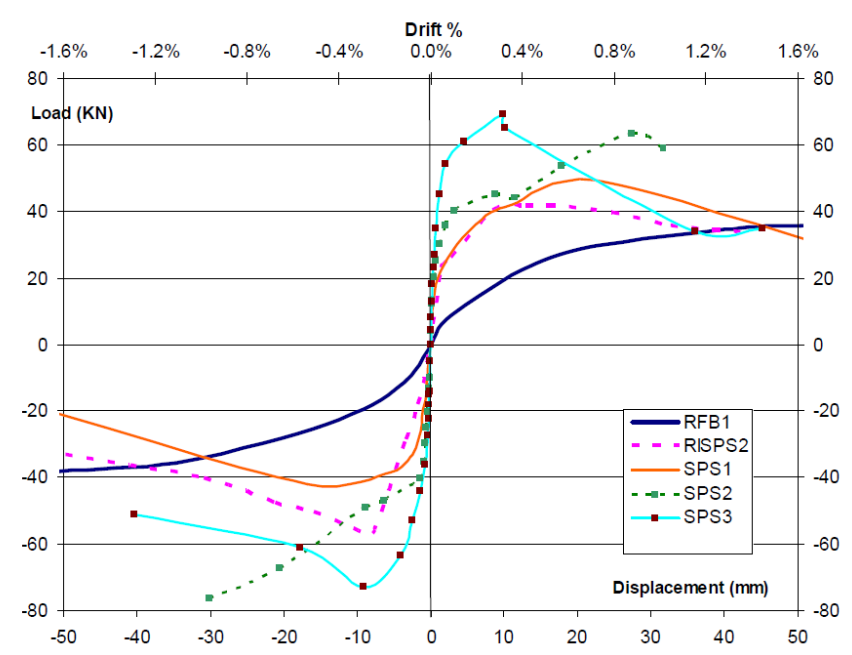

Fig. 17. Comparison of envelope curves.

With the increase in displacement and in the number of cycles, the hysteretic loops tend to be inclined. This modification corresponds to a reduction in stiffness. This characteristic permits a quantification of the damage (Colomb et al., 2008). The stiffness values of the hysteresis loops were evaluated and they are presented in graphical form in Fig. 19. The horizontal axe of the graphic is the maximum displacement of the cycle. The rate of stiffness degradation can also be calculated from these plots. The post yield behaviour is signified by monotonic degradation of stiffness. The stiffness of the strengthened specimens was significantly higher than the stiffness of the bare frame and reference infilled specimen.

The ability of the structure to survive an earthquake depends on its ability to dissipate the input energy. The energy dissipation with hysteretic damping was determined by calculating the areas enclosed by the hysteretic loaddisplacement loops. An estimate of the dissipated energy can

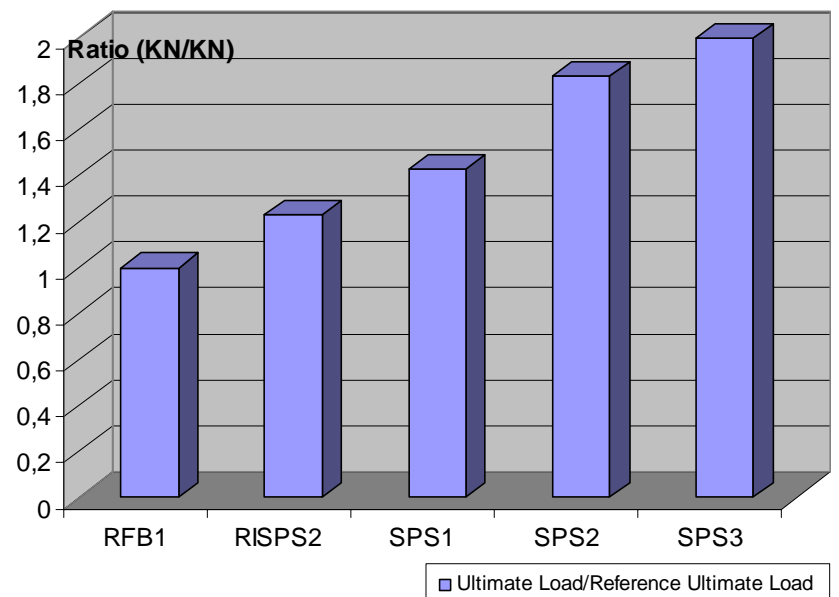

Fig. 18. Ratio of specimen ultimate load to the reference empty specimen's ultimate load.

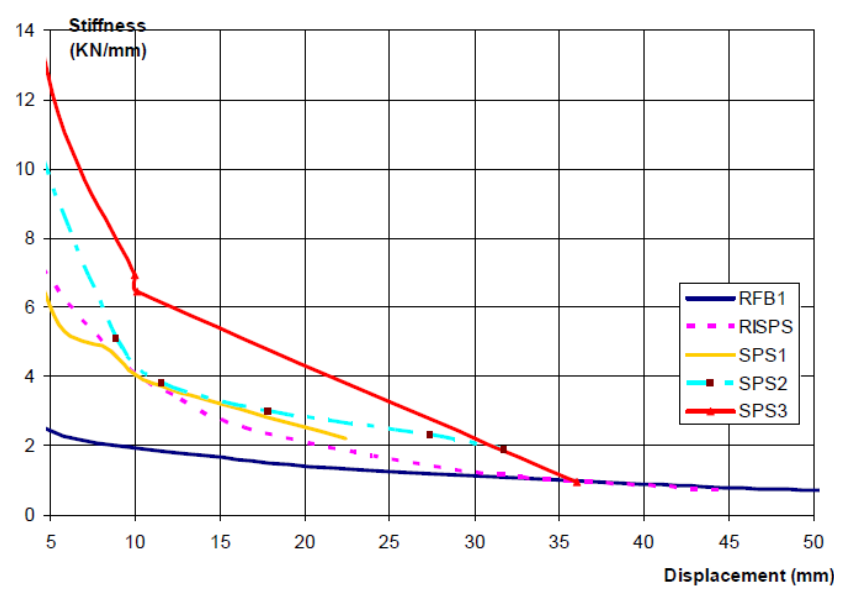

Fig. 19. Comparison of stiffness degradation.

be found by the area inside the load-displacement hysteresis loops. The width of the loop also depends on the maximum cycle displacement. Since imposed displacements were not the same for all specimens, energy dissipation values were normalized by dividing them into the corresponding cycle displacement. Cumulative energy values were evaluated by successive summation of the values. Figure 20 depicts the variation of cumulative dissipated energy as a function of cycle displacements. It may be noted that a wider loop (i.e. a large difference in ordinates in the ascending and the descending paths) would signify higher hysteretic damping.

Reference specimens dissipated the smallest amount of energy. Also specimen SPS1 displayed the poorest energy dissipation performance among the strengthened specimens. The energy dissipation capacity of strengthened specimens was significantly improved by the increase in the thickness of the plaster. Specimen SPS3 dissipated the largest amount of energy among the others (Kilic, 2009). 


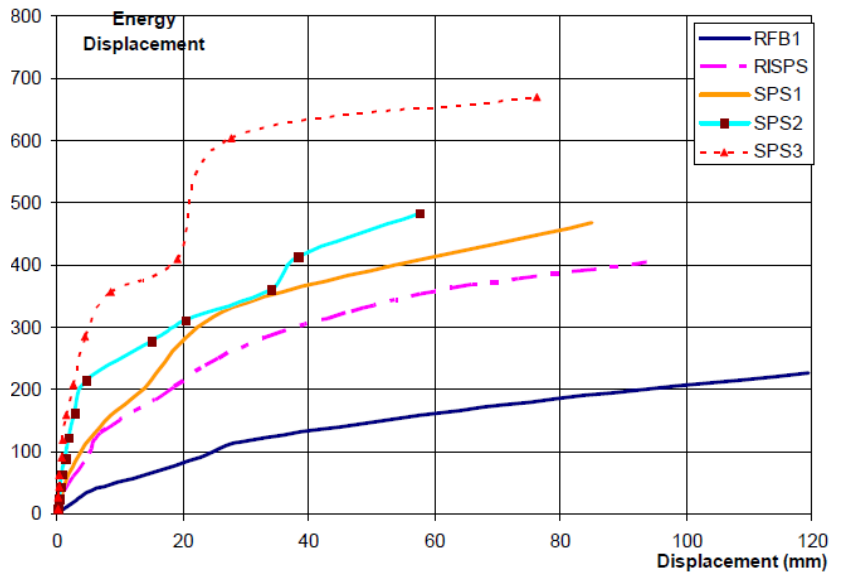

Fig. 20. Energy consumption comparisons.

\section{Discussion}

The examination of existing structures brings to light the initial design and/or construction mistakes and many existing structures in Turkey are inadequate based on the current seismic design codes. Since the potential for damage and loss of life during future seismic events is unacceptably high (Ghobarah and Elfath, 2001), it is important to improve the seismic resistance of systems that are found to be vulnerable. It is urgent to develop effective and economic seismic rehabilitation systems and to retrofit nonductile deficient RC buildings before an earthquake occurs.

One of the main reasons for catastrophic results after the earthquakes is the inadequacy in lateral stiffness. The necessary amount of strengthening must be provided to increase the lateral stiffness and to improve the seismic behaviour of buildings (Erdem et al., 2006).

The lateral stiffness of the frame systems can be increased by introducing new RC shear walls, diagonal steel bracings or the rehabilitation of existing brick infill walls. The significant effects of the infills on structural responses of frames have been realized by many researchers (Hao et al., 2002). The presence of infill walls can be beneficial and they enable the building to avoid collapse by limiting inter-storey deformations and providing additional base shear capacity to the existing structural system (Binici et al, 2007). Infills can completely change the distribution of damage throughout the structure (Dolšek and Fajfar, 2008). In order to rely on infill wall during an earthquake, they need to be strengthened so that they contribute to lateral load-carrying capacity. New Turkish Earthquake Code stated three strengthening techniques for brick infill walls. The aim is to convert the existing infill into a load carrying system acting as a castin-place concrete shear wall. The first method is the use of CFRP material. The diagonal CFRP strips that were used to retrofit brick masonry infilled reinforced concrete frames were effective in increasing lateral strength and lateral stiffness significantly. The second method is bonding precast concrete panels on hollow brick masonry infill walls.

The last method is to apply external mesh reinforcement, attached to the existing brick wall. Since this method was recently introduced in TEC-2007, few studies exist in the literature. In order to evaluate a new strengthening method which is rapid, practical, economical and occupant-friendly, an experimental study was conducted in the Structural Laboratory of the University.

In this paper, an experimental investigation was conducted to assess the behaviour of RC frames with external mesh reinforcement over the infill walls. The following conclusions were drawn based on the results of the cyclic tests.

The thickness of the plaster is important. Specimen SPS1 developed the lowest strength among the infilled specimens. This specimen lost $50 \%$ of its lateral load carrying capacity immediately after failure of the dowel anchorage with the mesh plaster composite. $15 \mathrm{~mm}$ plaster thickness is insufficient and is increased to $30 \mathrm{~mm}$ in other specimens. In real dimensions, $30 \mathrm{~mm}$ plaster thickness corresponds to $60 \mathrm{~mm}$ plaster thickness. Definitely the model study involves scale errors. At this point, an experimental study about the thickness of the plaster is needed in real dimensions. The frame may be one storey and only plaster thickness is the variable of the study.

Reinforcement details of the beam-column joints are important. A nonductile frame with bad reinforcement configuration cannot be strengthened with mesh reinforcement and plaster application which was presented in TEC-2007. The design engineer must solve the lap splice or confinement problems of the joints, first. A similar conclusion was also stated in the study of Altin et al. (2007).

For structures with very low concrete quality, this method is not an optimal choice. One can increase the strength of the brick walls with mesh reinforcement, but the frame may be damaged on the most forced points where stress concentration occurs. If the concrete quality is near to $10 \mathrm{MPa}$, jacketing of columns is needed. Rehabilitation of the existing brick walls with mesh reinforcement and the plaster application method can be applied after the jacketing.

Another discussion about the rehabilitation of the nonductile frames is the existing foundations. Increasing the shear/force capacity of the frame resulted in an increase on the demand of the foundations and the failure of the foundation should be avoided in any case. The design engineer must investigate and analyse the existing foundation. If the capacity of the existing foundation is not satisfactory, additional rehabilitation must be applied concerning the foundations.

Additional experimental work is needed to understand the frame behaviour. This test can be repeated with a concrete quality of $15 \mathrm{MPa}$. 
Acknowledgements. This study was a part of the research project supported by the Selcuk University Scientific Research Project Office (BAP). The authors acknowledge Haluk Sucuoglu and Bora Acun for their contribution in the planning the experimental work and Serra Z. Korkmaz for paper preparation.

Edited by: M. E. Contadakis

Reviewed by: four anonymous referees

\section{References}

Altin, S., Anil, O., Kara, M. E., and Kaya, M.: An experimental study on strengthening of masonry infilled RC frames using diagonal CFRP strips, Compos. Part B-Eng., 39(4), 680-693, 2008.

Altin, S., Anil, O., Kara, M. E., and Kaya, M.: Strengthening of RC nonductile frames with RC infills:An experimental study, Cement Concrete Comp., 30, 612-621, 2007.

Anil, O. and Altin, S.: An experimental study on reinforced concrete partially infilled frames, Eng. Struct., 29(3), 449-460, 2007.

Arslan, M. H. and Korkmaz, H. H.: What is to be learned from damage and failure of reinforced concrete structures during recent earthquakes in Turkey?, Eng. Fail. Anal., 14(1), 1-22, 2007.

Belmouden, Y. and Lestuzzi, P.: An equivalent frame model for seismic analysis of masonry and reinforced concrete buildings, Constr. Build. Mater., 23, 40-53, 2009.

Binici, B., Ozcebe, G., and Ozcelik, R.: Analysis and design of FRP composites for seismic retrofit of infill walls in reinforced concrete frames, Compos. Part B-Eng., 38, 575-583, 2007.

Colomb, F., Tobbi, H., Ferrier, E., and Hamelin, P.: Seismic retrofit of reinforced concrete short columns by CFRP materials, Compos. Struct., 82, 475-487, 2008.

Calvi, G. M.: The Behaviour of Frames Infilled With nonReinforced and MURFOR Reinforced Clay Brick Masonry Walls, Universita Degli Studi Di Pavia Dipartimento Di Meccanica Strutturale Laboratorio Materiali e Strutture, Via Abbiategrasso, Italy, 2000.

Dolsek, M. and Fajfar, P.: The effect of masonry infills on the seismic response of a four storey reinforced concrete frame a probabilistic assessment, Eng. Struct., 30, 3186-3192, 2008.

Dundar, C. and Kara, I. F.: Three dimensional analysis of reinforced concrete frames with cracked beam and column elements, Eng. Struct., 29, 2262-2273, 2007.

Erdem, I., Akyuz, U., Ersoy, U., and Ozcebe, G.: An experimental study on two different strengthening techniques for RC frames, Eng. Struct., 28(13), 1843-1851, 2006.
Firat, S., Arman, H., and Kutanis, M.: Assessment of liquefaction susceptibility of Adapazari City after 17th August, 1999 Marmara earthquake, Sci. Res. Essays, 4(10), 1012-1023, 2009.

Geng, Z. J., Chajes, M. J., Chouc, T.W., Yen, D., and Pan, C.: The retrofitting of reinforced concrete column to beam connections, Compos. Sci. Technol., 58, 1297-1305, 1998.

Ghobarah, A., El-Attar, M., and Aly, N. M.: Evaluation of retrofit strategies for reinforced concrete columns: a case study, Eng. Struct., 22, 490-501, 2000.

Ghobarah, A. and Elfath, H. A.: Rehabilitation of a reinforced concrete frame using eccentric steel Bracing, Eng. Struct., 23, 745-755, 2001.

Han, S. W. and Jee, N. Y.: Seismic behaviors of columns in ordinary and intermediate moment resisting concrete frames, Eng. Struct., 27:951-962, 2005.

Hao, H., Ma, G. W., and Lu, Y.: Damage assessment of masonry infilled RC frames subjected to blasting induced ground excitations, Eng. Struct., 24, 799-809, 2002.

Hueste, M. B. D. and Bai, J. M.: Seismic retrofit of a reinforced concrete flat-slab structure: Part I - seismic performance evaluation, Eng. Struct., 29, 1165-1177, 2007.

Kaltakci, M. Y., Arslan, M. H., Korkmaz, H. H., and Ozturk, M.: An investigation on failed or damaged reinforced concrete structures under their own-weight in Turkey, Eng. Fail. Anal., 14(6), 962969, 2007.

Kaltakci, M. Y., Arslan, M. H., Yilmaz, U. S., and Arslan, H. D.: A new approach on the strengthening of primary school buildings in Turkey: An application of external shear wall, Build. Environ., 43, 983-990, 2008.

Oliveto, G. and Decanini, L. D.: Repair and retrofit of a six storey reinforced concrete building damaged by the earthquake in south-east Sicily on the 13th December 1990, Soil Dyn. Earthq. Eng., 17, 57-71, 1998.

Onal, M.: Reinforcement of beams by using carbon fiber reinforced polimer in concrete building, Sci. Res. Essays, 4(10), 11361145, 2009.

Rocha, P., Delgado, P., Costa, A., and Delgado, R.: Seismic retrofit of RC frames, Comput. Struct., 82, 1523-1534, 2004.

Shing, P. B. and Mehrabi, A. B.: Behaviour and analysis of masonry-infilled frames, Prog. Struct. Eng. Mat., 4, 320-331, 2002.

Turkish Earthquake Code: Turkish Code for Buildings in Seismic Zones, Turkish Seismic Code, The Ministry of Public Works and Settlement, Ankara, Turkey, 2007.

Zou, X. K., Teng, J. G., Lorenzis, L. D., and Xia, S. H.: Optimal performance-based design of FRP jackets for seismic retrofit of reinforced concrete frames, Compos. Part B-Eng., 38, 584-597, 2007. 